\title{
PENGARUH GAYA HIDUP KONSUMEN MUSLIM TERHADAP ADOPSI SMARTPHONE APPLE (STUDI PADA MAHASISWA FAKULTAS EKONOMI DAN BISNIS UNIVERSITAS AIRLANGGA) ${ }^{1 !}$
}

\author{
Indra Rahmadi \\ Mahasiswa Program Studi S1 Ekonomi Islam - Fakultas Ekonomi dan Bisnis, Universitas \\ Airlangga \\ Email: indrarahmadi92@gmail.com \\ Ari Prasetyo \\ Departemen Ekonomi Syariah - Fakultas Ekonomi dan Bisnis - Universitas Airlangga \\ Email: ari_feunair@yahoo.co.id
}

\begin{abstract}
:
The purpose of this research is testing the influence of moslem consumer lifestyle to Apple smartphone adoption by students of Economics and Business Faculty of Airlangga University. This research uses quantitative approach and questionnaire for primary data collecting. The test was done using simple linear regression, where endogen variable $(Y)$ is apple smartphone adoption and exogen variable $(X)$ is moslem consumer lifestyle. Samples of this research was chosen using nonprobability sampling technique combined with accidental sampling and purposive sampling. Samples in this research are 100 students of Economics and Business Faculty of Airlangga University.

Based on the result of this research linear regression equation obtained is $Y=0.787+0.840$ $X$. The measurenment of the influence of moslem consumer lifestyle to Apple smartphone adoption by students of Economics and Business Faculty of Airlangga University has 0.290 (29\%) $R^{2}$ value. The result of this research shows that moslem consumer lifestyle has a significant influence with Apple smartphone adoption by students of Economics and Business Faculty of Airlangga University.
\end{abstract}

Keywords : Adoption, Lifestyle, Moslem Consumer, Smartphone.

I. PENDAHULUAN

Smartphone yang dalam beberapa tahun terakhir ini melanda seluruh dunia, dan termasuk di Indonesia kini menjadi fenomena tersendiri. Pada awalnya smartphone hanya ditujukan untuk kalangan atas. Tujuan dari kepemilikan smartphone tersebut adalah untuk menunjang aktivitas sehari-hari kepada pengguna yang memiliki mobilitas tinggi dengan kebutuhan yang multi-tasking. Sehingga untuk memenuhi kebutuhan tersebut, diciptakan device atau gadget yang mampu memenuhi hal tersebut yang kita kenal dengan smartphone.
Fenomena yang muncul sedikitnya ada dua hal. Memiliki smartphone memang karena di dasari kebutuhan dan beberapa di antaranya, pemilik smartphone 'hanya' untuk mempertahankan status sosial. Namun tidak menutup kemungkinan kedua fenomena itu ada dalam satu pemilik smartphone. Lain halnya dengan pemilik smartphone yang 'hanya' untuk mempertahankan status sosial. Fenomena ini muncul lebih banyak karena pengaruh eksternal. Dimana lingkungan tempat mereka berada kebanyakan rekannya, atasanya bahkan bawahanya menggunakan smartphone dengan

1) Jurnal ini merupakan bagian dari skripsi dari Indra Rahmadi, NIM : 041014149, yang diuji pada 2 februari 2015. 
merek, model dan jenis tertentu. Kepemilikan dengan fenomena yang satu ini terkesan hanya ikut-ikutan semata. Tidak jarang pemilik jenis ini hanya Tuntunan kepada umat mengenai cara-cara berkonsumsi yang baik telah diberikan oleh Islam. Islam membagi konsumsi menjadi dua, yaitu konsumsi untuk kebutuhan diri sendiri dan konsumsi untuk kebutuhan sosial. Konsumen Muslim yang taat, dirinya akan menyadari bahwa harta yang dimilikinya seharusnya dibelanjakan untuk kebutuhan pribadi dan untuk dibelanjakan di jalan Allah (Muflih, 2006:16-17). Seorang Muslim melakukan tindakan konsumsi seharusnya mencerminkan hubungan dirinya dengan Allah. Hal tersebut merupakan pembeda antara konsep konsumsi Islam dengan konsep konsumsi ilmu ekonomi lainnya. Umat Islam telah diajarkan untuk berkonsumsi dengan cara menjauhi produk-produk yang haram, tidak kikir, dan tidak tamak.

Produk-produk yang ditawarkan oleh fenomena produsen yang secara berlebihan dengan iklan-iklan yang provokatif tersebut direspon oleh para konsumen yang memiliki kecenderungan untuk berperilaku konsumtif, mengakibatkan munculnya konsumerisme. Kecenderungan untuk berkonsumsi secara berlebihan merupakan dorongan nafsu yang merupakan langkah-langkah setan yang harus dihindari konsumen Muslim.

Semakin pesatnya perkembangan teknologi informasi terutama internet menggunakan smartphone hanya fungsi dasarnya saja yang bisa juga dilakukan oleh handphone biasa.

maka akan memberikan pengaruh yang sangat besar terutama pada tingkat konsumsi masyarakat. Karena saat ini banyak orang yang memanfaatkan media internet sebagai media pemasaran dari bisnisnya. Yakni terbukti dengan semakin tingginya pengguna internet yang kemudian menjadi pasar yang sangat berpotensial tumbuhnya seorang pebisnis-pebisnis baru. Melalui media komunikasi inilah terjadi persaingan yang sangat kompetitif dalam menguasai pasar sehingga dapat melayani konsumen dengan baik.

Merek sendiri berfungsi untuk mengidentifikasi barang atau jasa dari seseorang atau sekelompok penyaji dan membedakannya dari produk sejenis dari penyaji lain (Kotler, 2006:163). Selain itu, merek adalah sesuatu yang dibentuk dalam pikiran pelanggan dan memiliki kekuatan membentuk kepercayaan pelanggan (Peter dan Olson, 2005:168). Jika perusahaan mampu membangun merek yang kuat dipikiran pelanggan melalui strategi pemasaran yang tepat, perusahaan akan mampu membangun mereknya. Merek merupakan identitas sebuah produk yang dapat dijadikan sebagai alat ukur apakah produk itu baik dan berkualitas.

Menurut penelitian Fatchun (2010:1), pada prinsipnya nilai penting dari sebuah merek adalah terwujudnya 
kesadaran (awareness) yang merupakan core competencybagi perusahaan. Karena tolak ukur kekuatan sebuah merek adalah sebuah gambaran situasi dan kondisi dimana konsumen merasa sangat mengenal dan memahami suatu produk, baik itu dari sisi kualitas dan atau ciri yang dimiliki oleh perusahaan di antara merek yang ada dan atau ditawarkan di pasar (boyle, 2007:124). Perusahaan berusaha untuk mengemas strategi komunikasi pemasarannya melalui promotional tools yang tepat guna memperkenalkan produknya ke masyarakat. Dalam pembentukan awareness dibutuhkan komunikasi pemasaran, dimana ada pesan yang diterima konsumen sehingga ia sadar akan adanya merek tertentu.

Shimp (2004:35) mengungkapkan bahwa brand awareness merupakan dimensi dasar dari ekuitas merek, mencapai brand awareness adalah tantangan untuk merek baru, mempertahankan posisi brand awareness adalah tugas yang harus dihadapi semua merek yang sudah berdiri.

Brand awareness memiliki dampak langsung terkuat pada pendapatan perusahaan dibandingkan dengan elemen brand equity yang lain (Tjiptono, 2005:53).

Berdasarkan latar belakang diatas, dapat disimpulkan bahwa tidak semua pemilik smartphone Apple menggunakan smartphonenya untuk menunjang kegiatan sehari-hari namun hanya untuk gaya hidup semata.Fenomena tersebut menjadi latar belakang penulis tertarik untuk meneliti tentang Pengaruh Gaya Hidup Konsumen Muslim Terhadap Adopsi Smartphone Apple Pada Mahasiswa Fakultas Ekonomi dan Bisnis Universitas Airlangga.

Berdasarkan uraian pada latar belakang diatas, maka dapat dirumuskan bahwa masalah yang ingin diteliti adalah apakah Gaya Hidup Konsumen Muslim memiliki pengaruh secara signifikan terhadap Adapsi Smartphone Apple pada Mahasiswa Fakultas Ekonomi dan Bisnis Universitas Airlangga?

Tujuan penelitian ini adalah untuk meneliti dan mengetahui apakah terdapat pengaruh signifikan antara gaya hidup konsumen Muslim terhadap adopsi smartphone Apple pada mahasiswa Fakultas Ekonomi dan Bisnis Universitas Airlangga.

\section{LANDASAN TEORI}

Gaya hidup secara luas didefinisikan sebagai cara hidup yang diidentifikasikan oleh bagaimana orang menghabiskan waktu mereka (aktifitas), apa yang mereka anggap penting dalam lingkungannya (ketertarikan) dan apa yang mereka pikirkan tentang diri mereka sendiri dan juga dunia di sekitarnya (pendapat) (Sutisna, 2002:145). Sedangkan menurut Kotler (2006:210), gaya hidup secara luas didefinisikan sebagai pola hidup seseorang didunia yang terungkap pada aktifitas, minat dan opininya.

Menurut Said (2008:53), para Sarjana Muslim mengelompokkan manusia menjadi tiga kelompok : 
1. Materialistis (Dahriyyin) adalah mereka yang hidup hanya untuk dunia dan kesenangan, berperilaku materialis dan tidak mempercayai adanya akhirat dimana nantinya akan dimintai pertanggungjawaban.

2. Spiritualis (Rabbaniyun) adalah mereka yang tidak memiliki pandangan yang jelas mengenai kepribadiannya. Paham ini lebih menekankan pada aspek moral, kerohanian dan mengesampingkan aspek kebendaan dalam kehidupan manusia, jadi semua aktifitas ekonomi bertumpu pada do'a.

3. Insan Sejati (Al-Mukminun) adalah mereka yang menerima kehidupan dunia sebagai tempat menanam benih bagi kehidupan di akhirat dan percaya kepada Allah SWT dan mengetahui makna kehidupan dunia dan akhirat.

Muflih (2006:4) mengatakan bahwa perilaku konsumen dalam Islam harus mencerminkan hubungan dirinya dengan Allah SWT. Setiap pergerakan diri yang berbentuk belanja sehari-hari, tidak lain adalah manifestasi dzikir dirinya atas nama Allah SWT sehingga konsumen akan lebih memilih jalan yang dibatasi Allah SWT dengan tidak memilih barang haram, tidak kikir, dan tidak tamak supaya hidupnya selamat baik di dunia maupun di akhirat.

Ajaran syariah dalam bentuk konsumsi yaitu mengkonsumsi halal dan haram, pelarangan terhadap ishraf (berlebihan) yaitu bermewah-mewahan dan bermegah-megahan, konsumsi sosial, dan aspek-aspek normatif lainnya.
Dijelaskan dalam tafsir Al Mishbah bahwa dalam berkonsumsi, seorang konsumen Muslim harus memperhatikan produk-produk yang dikonsumsi agar terhindar dari hal-hal yang diharamkan olah Allah serta tidak berlebihan. Berdasarkan berbagai kelompok Muslim yang telah dijelaskan tersebut, maka beragam pula gaya hidup dari masingmasing kelompok tersebut. Seharusnya sebagai seorang Muslim tidak hanya mementingkan akhirat ataupun dunia saja, namun antara dunia dan akhirat seimbang keberadaanya.

"Adoption is an individuals"s decision to become a regular user of a product" (Kotler, 2006:610) yang mempunyai pengertian bahwa adopsi adalah keputusan individu untuk menjadi pengguna sebuah produk. Menurut Suryani (2008:321), pandangan tradisional mengenai proses adopsi mengikuti tahapan AIETA (Awareness, Interest, Evaluation, Trial, Adoption), yang dijelaskan sebagai berikut :

1. Tahap Awareness (kesadaran)

Tahapan ini untuk mengetahui adanya ide baru tapi informasi yang sangat terbatas. Contoh konsumen mendengar bahwa ada laptop yang ringan dan praktis, namun konsumen masih belum tahu manfaat dan keunggulan lainnya.

2. Tahap Interest (menaruh minat) Tahapan ini konsumen mulai menaruh minat terhadap inovasi dan mencari informasi lebih banyak mengenai inovasi tersebut. Dengan cara mencari di media 
cetak atau dari TV atau bertanya dari orang lain.

3. Tahap Evaluation (penilaian)

Tahapan ini konsumen melakukan penilaian terhadap produk baru berdasar informasi yang diperoleh dan mencoba mencocokkan dengan kebutuhan sebelum memutuskan untuk mencoba. Kemudian konsumen akan membandingkan produk yang baru dengan produk lain yang ada di pasar, sehingga timbul keputusan mencoba.

d. Tahap Trial (pencobaan)

Tahapan ini konsumen menggunakan inovasi baru untuk memastikan ide dalam skala kecil untuk menentukan kegunaannya apakaah sesuai dengan diri konsumen tersebut.

e. Tahap Adoption (penerimaan)

Tahapan ini konsumen berdasarkan evaluasinya selama mencoba produk dan merasakan hasilnya untuk pemakaian secara kontinu

\section{METODE PENELITIAN}

Penelitian ini menggunakan pendekatan kuantitatif, yaitu dengan mengumpulkan data yang berupa angka. Data yang berupa angka ini nantinya akan diolah dan dianalisis untuk mendapatkan suatu informasi ilmiah dibalik angka-angka tersebut (Martono, 2011:20).

Setelah data terkumpul, kemudian dianalisis dengan metode regresi linier sederhana (Simple Linear Regression Model). Model analisis ini dilakukan untuk mengetahui pengaruh atau hubungan variabel endogen (gaya hidup konsumen muslim) dan variabel eksogen (adopsi smartphone Apple).

Berdasarkan variabel-variabel yang digunakan, maka bentuk analisis regresi linier sederhana dapat dirumuskan sebagai berikut :

$$
Y=\beta_{0}+\beta_{1} X+\varepsilon
$$

Keterangan:

$$
\begin{array}{ll}
\mathrm{Y} & =\text { Adopsi Smartphone Apple } \\
\mathrm{X} & =\text { Gaya Hidup Konsumen Muslim } \\
\beta_{0} & =\text { Konstanta } \\
\beta_{1} & =\text { Koefisien Regresi } \\
\varepsilon & =\text { Variabel Error }
\end{array}
$$

Dari model analisa regresi linear yang digunakan, terdapat beberapa asumsi klasik yang dapat digunakan untuk mengestimasi hasil agar tidak ada penyimpangan sehingga dapat memberikan informasi yang sesuai dengan data yang tersedia. Asumsi klasik tersebut adalahuji normalitas.

\section{Populasi dan Sampel}

Populasi adalah wilayah generalisasi yang terdiri atas subjek yang mempunyai kualitas dan karakteristik tertentu yang diterapkan oleh peneliti untuk dipelajari dan kemudian ditarik kesimpulannya (Ansori dan Iswati, 2009:92). Populasi merupakan sekelompok orang, kejadian atau segala sesuatu yang mempunyai karakteristik tertentu (Indriantoro dan Supomo, 2002:115-116). Populasi yang digunakan dalam penelitian ini adalah mahasiswa Muslim Fakultas Ekonomi dan Bisnis Universitas Airlangga yang menggunakan smartphone Apple.Sampel adalah bagian dari jumlah dan karakteristik yang dimiliki 
oleh populasi (Ansori dan Iswati, 2009:94).Ukuran sampel yang digunakan pada penelitian ini adalah sebanyak 100 responden, sesuai dengan pendapat Aaker (1998:393) bahwa jumlah minimum sampel yang diambil dalam suatu penelitian adalah 100 responden.

\section{HASIL DAN PEMBAHASAN}

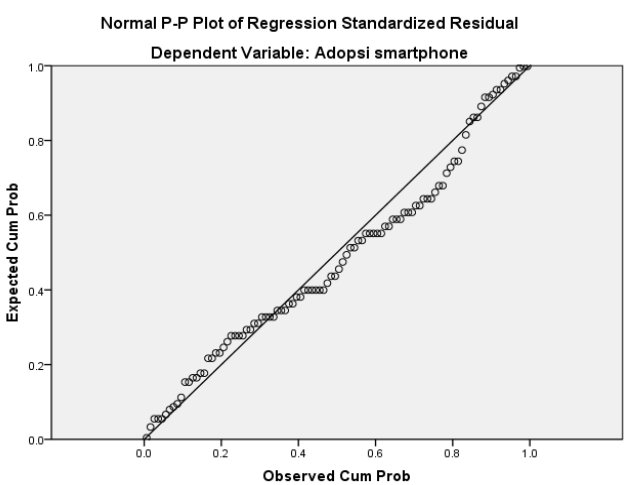

Sumber : Hasil Penelitian, 2014 (diolah)

Gambar di atas menunjukkan bahwa titiktitik menyebar secara teratur di sekitar garis lurus melintang, dan mengikuti arah garis diagonal, sehingga dapat dinyatakan bahwa data yang digunakan adalah normal.

Tabel 1.

Hasil Uji Regresi Linear Sederhana

\begin{tabular}{|c|c|c|c|c|}
\hline Variabel & \multicolumn{2}{|c|}{ Koefisien } & t hit. & Sign. \\
\cline { 2 - 3 } & $\begin{array}{c}\text { Koef. } \\
\text { Reg. }\end{array}$ & Beta & & \\
\hline Konstanta & 0.787 & & 2,077 & 0,040 \\
\hline Gaya Hidup & 0,840 & 0,539 & 6,330 & 0,000 \\
\hline $\begin{array}{l}\text { Multiple R }=\mathbf{0 , 5 3 9} \\
\text { R Square }=\mathbf{0 , 2 9 0}\end{array}$ & $\begin{array}{l}\mathbf{N}=100 \\
\text { Sign }=\mathbf{0 , 0 0 0}\end{array}$ \\
\hline
\end{tabular}

Sumber : Hasil Penelitian, 2014 (diolah)

Berdasarkan hasil regresi sederhana, maka persamaan regresi yang dapat dibuat adalah sebagai berikut :

$Y=0.787+0,840 X$

Dimana $: Y=$ Adopsi Smartphone Apple
X= Gaya Hidup Konsumen Muslim

Koefisien regresi yang bertanda positif menunjukkan perubahan yang searah antara variabel bebas (eksogen) terhadap variabel terikat (endogen). Penjelasan untuk persamaan tersebut adalah:

1. Jika tidak ada pengaruh dari variabel Gaya Hidup dan yang lain dianggap konstan maka Adopsi Smartphone Apple adalah sebesar 0.787

2. Koefisien regresi Gaya Hidup (X) sebesar 0,840, berarti jika variabel bebas yaitu Gaya Hidup ditingkatkan dan variabel lain dalam keadaan konstan maka Adopsi Smartphone Apple juga akan meningkat dengan koefisien regresi sebesar 0,840.

Tabel 2

Hasil Uji Regresi Secara Parsial (Uji †)

\begin{tabular}{|l|l|l|}
\hline Variabel & $t$ & $\begin{array}{l}\text { Tingkat } \\
\text { signifikansi }\end{array}$ \\
\hline \hline $\begin{array}{l}\text { Gaya } \\
\text { Hidup }\end{array}$ & 6.330 & 0.000 \\
\hline
\end{tabular}

Sumber : Hasil Penelitian, 2014 (diolah)

Nilai uji $†$ untuk variabel Gaya Hidup (X) adalah sebesar 6.330 dengan tingkat signifikasi 0,000 . Tingkat signifikasi uji $\dagger$ dalam penelitian ini sebesar 0,000 merupakan besaran signifikansi yang lebih kecil dari tingat signifikansi yang dijinkan (a) yaitu 0,05 , sehingga dapat dinyatakan bahwa Ho ditolak yang berarti ada pengaruh secara parsial antara variabel Gaya Hidup Konsumen Muslim (X) terhadap variabel Adopsi Smartphone 
Apple pada Mahasiswa Fakultas Ekonomi dan Bisnis Universitas Airlangga (Y).

Berdasarkan hasil analisi koefisien korelasi dalam penelitian ini, disebutkan bahwa variabel Gaya Hidup Konsumen Muslim (X) berpengaruh signifikan dengan variabel Adopsi Smartphone Apple (Y). Hubungan antar variabel juga menunjukkan tanda positif. Hubungan yang positif antar variabel tersebut dapat diartikan bahwa setiap peningkatan variabel bebas (eksogen) akan berpengaruh terhadap peningkatan variabel terikat (endogen), begitu pula sebaliknya setiap penurunan variabel bebas (eksogen) akan berpengaruh pula pada penurunan variabel terikat (endogen).

Hasil uji regresi dengan menggunakan uji $\dagger$ menunjukkan besar nilai $t$ sebesar 6.330 dengan tingkat signifikan $\leq 0,05$, yaitu 0,000 . Hasil tersebut menunjukan bahwa tinggi rendahnya adopsi smartphone Apple pada mahasiswa Fakultas Ekonomi dan Bisnis Universitas Airlangga salah satunya dipengaruhi oleh faktor gaya hidup konsumen muslim. Dengan demikian, hasil analisis ini menunjukan bahwa hipotesis dapat diterima, artinya gaya hidup konsumen muslim mempunyai pengaruh positif yang signifikan terhadapadopsi smartphone Apple pada mahasiswa Fakultas Ekonomi dan Bisnis Universitas Airlangga.

Selain itu dukungan terhadap hasil penelitian sebelumnya dari Indah Nurlaily Rachmania (2013) yang berjudul
Pengaruh Gaya Hidup Konsumen Muslimah Terhadap Adopsi Belanja Online Pada Produk Fashion. Hasil dari penelitian ini signifikan, gaya hidup konsumen muslimah berpengaruh positif terhadap adopsi belanja online.

Berdasarkan hasil pengolahan data dari 100 responden, menunjukan bahwa secara keseluruhan rata-rata tanggapan responden pada gaya hidup konsumen muslim termasuk tinggi dengan nilai mean variabel bebas (eksogen) sebesar 2.78 .

\section{KESIMPULAN}

Berdasarkan hasil analisisi dan pengujian hipotesis pada bab sebelumnya maka dapat diambil kesimpulan bahwa variabel gaya hidup konsumen muslim berpengaruh secara langsung, positif, dan signifikan terhadap adopsi smartphone Apple pada mahasiswa Fakultas Ekonomi dan Bisnis Universitas Airlangga. Hal ini menujukan bahwa hipotesis dalam penelitian ini yang menyatakan bahwa variabel gaya hidup konsumen Muslim berpengaruh signifikan terhadap variabel adopsi smartphone. Secara teoritis hasil penelitian ini mengandung makna bahwa Variabel gaya hidup konsumen Muslim merupakan salah satu intrumen yang dapat mempengaruhui adopsi smartphone Apple pada mahasiswa Fakultas Ekonomi dan Bisnis Universitas Airlangga.

\section{DAFTAR PUSTAKA}

Aaker, David A., Kumar, George S. Day. 1998 Marketing research. 
6thEdition.Canda : john Willey and Sons, Inc.

Fatchun. Hasyim. 2010. Model Perilaku Pembelian Konsumen Berdasarkan Pengaruh Langsung dan Tidak Langsung Komunikasi Pemasaran Terpadu. (Studi Kasus Pada Penerimaan Mahasiswa Baru Politeknik Negeri Semarang 2009/2010). Jurnal teknis Vol. $6 \mathrm{No} .1: 37-45$

Indriantoro, Nur dan Bambang Supomo. 2002. Metodologi Penelitian Bisnis untuk Akuntansi dan Manejemen. Edisi Pertama. Yogyakarta:BPFE

Kotler, Philip. 2006. Manajemen Pemasaran. Edisi Kesebelas. Jilid 1. Terjemahan oleh Benyamin Molan. 2006. Jakarta : Indeks.

Martono, Nanang. 2010. Metode Penelitian Kuantitatif. Jakarta: Raya Grafindo Persada.

Muflih, Muhammad. 2006. Perilaku Konsumen dalam Perspektif Ekonomi Islam. Jakarta : PT. Raja Grafindo Persada.

Peter, J Paul and jerry C. Olson, 2005, Consumer Behavior and Marketing Strategy, 7th edition, New York: McGraw Hill

Said, Syihabudin dan Ma'zumi. 2008. Falsafah dan Perilaku Ekonomi Islam. Jakarta : Diadit media.

Shimp, Terance A. 2004. Periklanan dan promosi aspek tambahan Komunikasi Pemasaran Terpadu,Erlangga, Jakarta. Suryani, Tatik. 2008. Perilaku Konsumen Implikasi pada Strategi Pemasaran. Yogyakarta : Graha IImu
Sutisna. 2002. Perilaku Konsumen dan Komunikasi Pemasaran. Bandung : Rosda.

Tjiptono, Fandy. 2005. Pemasaran Jasa. Edisi Pertama. Bayu Media Publishing. Malang. 